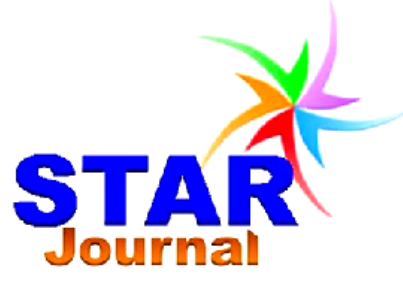

ISSN: 2226-7522(Print) and 2305-3327 (Online) Science, Technology and Arts Research Journal July-Sep 2012, 1(3): 01-07 www.starjournal.org

Copyright $\odot 2012$ STAR. All Rights Reserved

\title{
Sesame (Sesame indicum L.) Crop Production in Ethiopia: Trends, Challenges and Future Prospects
}

\author{
Zerihun J. \\ Department of Plant Science, College of Agriculture and Natural Resources, Wollega University. \\ Post Box No: 692, Nekemte, Ethiopia
}

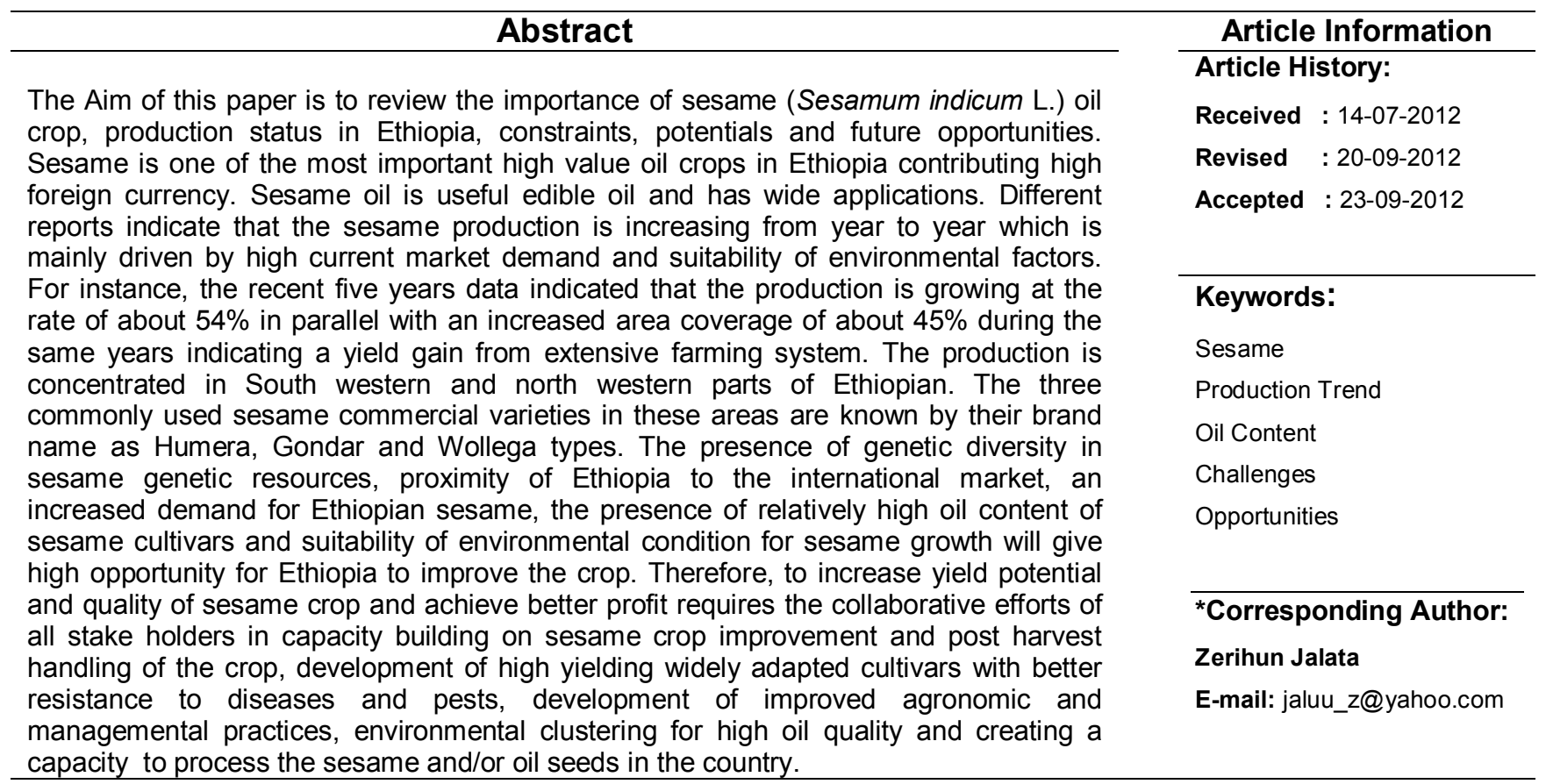

\section{INTRODUCTION}

Sesame (Sesamum indicum L. Pedaliaceae) is one of the oldest oil crops and thought to have originated in Africa (Brar and Ahuja, 1979; Ram et al., 1990). It is widely grown in tropical and subtropical regions. Its production is often concentrated in marginal and sub marginal lands (Ashri, 1998). Ethiopia ranks among the top six world producers of sesame seed and linseed. The Ethiopian government has indicated that the oil seeds such as sesame, niger and safflower seeds as high-priority export crops and ranks the second biggest export earner. Thus, production growth and quality improvement of oilseeds can substantially contribute to the economic development at national, regional and at family level (Wijnands et al., 2009). Sesame is the third most important oil crop in Ethiopia and occurs both as cultivated and wild. Sesame in Ethiopia shows a high phenotypic diversity for number of days to maturity, plant height, pod shape and size, and for seed size and color (FAO, 1996). Sesame production is increasing in Ethiopia especially in southwest and northwestern parts of the country which is driven by high market value and suitability of environmental conditions (Wijnands et al., 2007). However, lack of wider adapting cultivars, shattering of capsules at maturity, non-synchronous maturity, poor stand establishment, lack of fertilizer responses, profuse branching, and low harvest index are the major constraints in sesame production 
Zerihun

worldwide (Ashri, 1994). Sesame being the most important export oil crop in Ethiopia, however, there is no adequate information available in Ethiopia. Therefore, the purpose of this paper is to review the importance of sesame seed, production trend, challenges, potentials and future opportunities of the crop.

\section{Origin and Distribution of Sesame}

Sesame (Sesamum indicum L. Pedaliaceae) is a broad leafed plant and with mostly indeterminate inflorescence (Tashiro et al., 1991). Though there are dehiscent and non-dehiscent types, but most sesame seed is produced with dehiscent types. When the capsules on dehiscent cultivars mature, they split from top down wards over about two thirds of their length and shed their seeds if not timely harvested causing yield losses. The genus sesamum $(2 n=26)$ is a member of pedaliaceae family which contains 16 genera and 60 species which most occur in Africa (Ashri, 2007). Sesame diversity centers have been identified in India, China, Central Asia, Near East and Ethiopia (Zeven and Zhukovsky, 1975; Hawkes, 1983). Though there is no definite findings on the origin of sesame, Ethiopia is considered to be the center of cultivated sesame (Weiss, 1983). In Ethiopia, sesame occurs both as cultivated and wild (FAO, 1996). Brar and Ahuja (1979) and Ram et al. (1990) reported that the origin would be in Africa. Bedigian (1985) considered East Africa and India as early origins for Sesame. Beside this, about 36 species of Sesamum are said to exist and more of them are located in Africa, with a few in India (Kobayashi, 1981). In their study on 32 sesame accessions which were collected from five geographical regions representing the proposed diversity centers, Laurentin and Karlovsky (2006) found that there is very high genetic diversity among sesame collections from these different regions. While, the genetic diversity of Ethiopian sesame landraces and cultivars showed the existence of great genetic variability between the landraces and SSR markers were established for further diversity analyses of Ethiopian sesame and establishment of a core collection (Daniel et al., 2010). This suggests that effective utilization of the available sesame genetic resources will create a better chance for sesame crop improvement in Ethiopia.

\section{Importance of Sesame Seeds}

Annual plants such as sesame, linseed, soybeans, corn, cottonseed, groundnut, sunflower, safflower and rapeseed are the largest sources of vegetable oils (Frank, 1998; O'Brien, 1998). Sesame is a high value food crop which is
Sci. Technol. Arts Res. J., July-Sep 2012, 1(3): 01-07

an important source of edible oil and is also used as a spice (in bakeries). The seed oil ranges from $50-60 \%$ containing high proportion of natural antioxidants such as sesamolin, sesamin and sesamol which gives excellent stability (Brar and Ahuja, 1979; Hatam and Abbasi, 1994; Uzun et al., 2002) and $19-25 \%$ protein (Ashakumary et al., 1999). Oil content ranging from about 45 to $53 \%$ has also been reported in Ethiopia (Zenebe and Hussien, 2009). Genetic and environmental factors influence the oil content and fatty acid compositions of sesame (Carlsson et al., 2008) and the indeterminate cultivars accumulated more oil than determinate ones (Uzun et al., 2002). The principal unsaturated fatty acids are oleic and linoleic with about $40 \%$ of each and $14 \%$ saturated fatty acids. The seeds are very rich in iron, magnesium, copper, calcium and vitamin $B_{1}$ (thiamine) and $E$ (tocopherol). It contains lignin, including unique content of sesamin which are phytoestrogen with antioxidant and anticancer properties. The seed also contain phytosterols associated with reduced levels of blood cholesterol (Bedigian, 2004). Similarly Balasubramaniyan and Palaniappan (2001) also reported seed containing all essential amino acids and fatty acids. Sesame is also a good source of vitamin $E$ and minerals such as calcium and phosphorous. After oil is extracted the remaining meal contains $42 \%$ protein rich in tryptophan and methonine which is an excellent feed for animal (Hatam and Abbasi, 1994). Other industrial uses of sesame oil include pharmaceuticals in preparation of antioxidants, cosmetics and synergists for insecticides (Salunkhe and Desai, 1986).

\section{Sesame Production \\ Environmental Requirement for Sesame}

Sesame is a warm season annual crop which is primarily adapted to areas with long growing seasons and well drained soils. Sesame prefers slightly acid to alkaline soils ( $\mathrm{pH} 5-8$ ) with moderate fertility. Clay soils are more prone to water logging. Sesame will not withstand water over the stem because it limits oxygen presence to the roots and suffocates the plants. Even if the plants do not die, they will be more susceptible to root rots and will yield less. Whereas it is a heat tolerant crop (Langham et al., 2010). So, sesame will perform best on fertile and well-drained soils such as silt loams. It is adapted to sandy loam soils provided there is adequate moisture during seedling establishment and it has been grown satisfactorily on silty clay loam soils. Planting sesame is the most critical phase of its management. Successful establishment of sesame requires careful seedbed preparation 
Zerihun

and close attention to soil moisture. Sesame will not emerge from soils that are even slightly crusted and needs fairly warm soil temperatures of $70{ }^{0} \mathrm{~F}$ or more.

\section{World Sesame Production}

India and China (Table 1) are the world's largest producers of sesame, followed by Myanmar, Sudan, Uganda, Ethiopia, Nigeria, Tanzania, Pakistan and Paraguay (FAOSTAT, 2008). In 2008, the total world sesame production was about 3.54 million tons that was grown on 7.42 million hectares. India was a major sesame producer, accounting for $40 \%$ of the world's sesame area and $27 \%$ of world production (Sharma, 1994).

\section{Trends and Future Prospects of Sesame Production in Ethiopia}

Ethiopia is one of the major centers of origin and/or diversity for several oil crops. Gomenzer (Brassica carinata), noug (Guizotia abyssinica), sesame (Sesamum indicum) and linseed (Lens culinaris) are the major indigenous oil crops having considerable diversity in the country. These crops are primarily used as sources of oil for local consumption and also contribute to the national economy through import substitution by helping save scarce foreign currency spent for importing cooking oil. Oilseeds cover a total of $7.63 \%$ (about 855,000 hectares) of the grain crop area and $3.83 \%$ (6.6 million quintals) of yield production to the national grain production. For instance, Neoug (Niger seed), sesame and linseed covered $2.8 \%, 2.48 \%$ and $1.61 \%$ of grain crop area, respectively; and about 1.11\%, 1.27\% and $0.91 \%$ of the grain production, respectively (CSA, 2009). Sesame is the major oil seed in terms of exports, accounting for over $90 \%$ of the values of oil seeds exports following coffee.

The oilseeds sector is one of Ethiopia's fastest growing and important sectors, both in terms of its foreign exchange earnings and as a main source of income for over three million Ethiopians. Study reports indicate that Ethiopia is among the six producers of sesame seed, linseed and niger seed in the world (Wijnands et al., 2009). The major sesame seed producing regions are situated in the North West and South West Ethiopian in Humera, North Gondar and Wollega (Wijnands et al., 2007; Dawit and Meijerink, 2010; CSA, 2011). For instance, the main source of farmers' income in western Tigray was sesame sales (www.docstoc.com/docs/..l Livelihood-Profile-Tigray-Region), Ethiopia
Sci. Technol. Arts Res. J., July-Sep 2012, 1(3): 01-07

imports large amounts of edible oil, mainly palm oil and this value is about 40 to $50 \%$ of the export earnings of oil seeds; in 2008 the value of edible oil imports more or less on the same level as the value of oil seeds exports (Wijnands et al., 2009). This shows that the requirement of refining oil seeds in the country will be more advantageous. Oil seeds production trends of Ethiopia from 2000/01-2010/11(Figure 1) showed that the three major oil crops, sesame, niger seed and linseed were relatively higher in production while the production of ground nut and rape crop seeds is lower and stagnant. Of oil crops, sesame production trend indicates that almost the production is increasing on yearly basis almost linearly from 19000 tons in 2000/1 to 327,700 tons in 2010/11 (Figure 1) and its area coverage is also increasing from year to year. In Ethiopia, central statistical agency data showed that the national productivity of sesame is about 8.52 quintals/ha (CSA, 2010/11) which is higher than the yield under traditional condition (5.67 quintals/ha) which was reported in India but lower than the yield from experimental station (12.05 quintals/ha) in the same country (Dhandhalya and Shiyani, 2009). Another base line survey report in Mozambique indicated that average yield of 3 quintals per hectare was obtained nationally whereas improved sesame varieties had yield potential of up to 15 quintals/ha under good managemental condition in Mozambiqu (Buss, 2007). On the other hand, the world productivity of sesame is average of 4.4 quintals/ha in the year 2006-07 (http://faostat.fao. org/site/567/DesktopDefault.aspx?PagelD=567). Compared to world productivity, the Ethiopian sesame productivity is relatively higher but this does not mean that maximum yield potential has been achieved. Considering only the last five years data (2006/7-2010/11), sesame production in Ethiopia is growing at the rate of about $54 \%$ (Figure 1). Similarly, the area coverage of the same crop during the same years was increased from 211,312 hectares in 2006/7 (CSA, 2007/8) to nearly 384,683 hectares in $2010 / 11$ (CSA, 2010/11) indicating an increment of area coverage at about $45 \%$. This also shows that an increased sesame production was mainly dependent on extensive farming than intensive. This indicates that the use of improved technologies would ultimately result to achieve maximum yield from this large area size.Thus, it appears that the current increment of sesame area coverage and production is highly influenced by an increasing market value in international market for Ethiopian sesame seed. 
Table 1: World's major sesame producers and production status (in 2006).

\begin{tabular}{clcccc}
\hline No. & Country & $\begin{array}{c}\text { Area } \\
\text { (in ha) }\end{array}$ & $\begin{array}{c}\text { Production } \\
\text { (in tons) }\end{array}$ & $\begin{array}{c}\text { Productivity } \\
\text { (in tons/ha) }\end{array}$ & $\begin{array}{c}\text { \% Share In } \\
\text { World } \\
\text { Production }\end{array}$ \\
\hline 1 & India & 1900 & 628 & 0.33 & 18.8 \\
2 & China & 1640 & 665 & 1.03 & 19.9 \\
3 & Myanmar & 1570 & 580 & 0.36 & 17.3 \\
4 & Sudan & 1270 & 200 & 0.15 & 05.9 \\
5 & Uganda & 0276 & 166 & 0.60 & 04.9 \\
6 & Ethiopia & 0219.6 & 159 & 0.72 & 04.7 \\
7 & Nigeria & 0196 & 100 & 0.51 & 02.9 \\
8 & Pakistan & 0068.2 & 029.5 & 0.43 & 00.8 \\
9 & Bangladesh & 0080.0 & 050.0 & 0.62 & 01.4 \\
10 & others & 1319.6 & 760.4 & 0.57 & 22.7 \\
\hline \multicolumn{7}{c}{ Total } & & $\mathbf{3 3 3 7 . 9}$ & $\mathbf{0 . 4 4}$ & \\
\hline
\end{tabular}

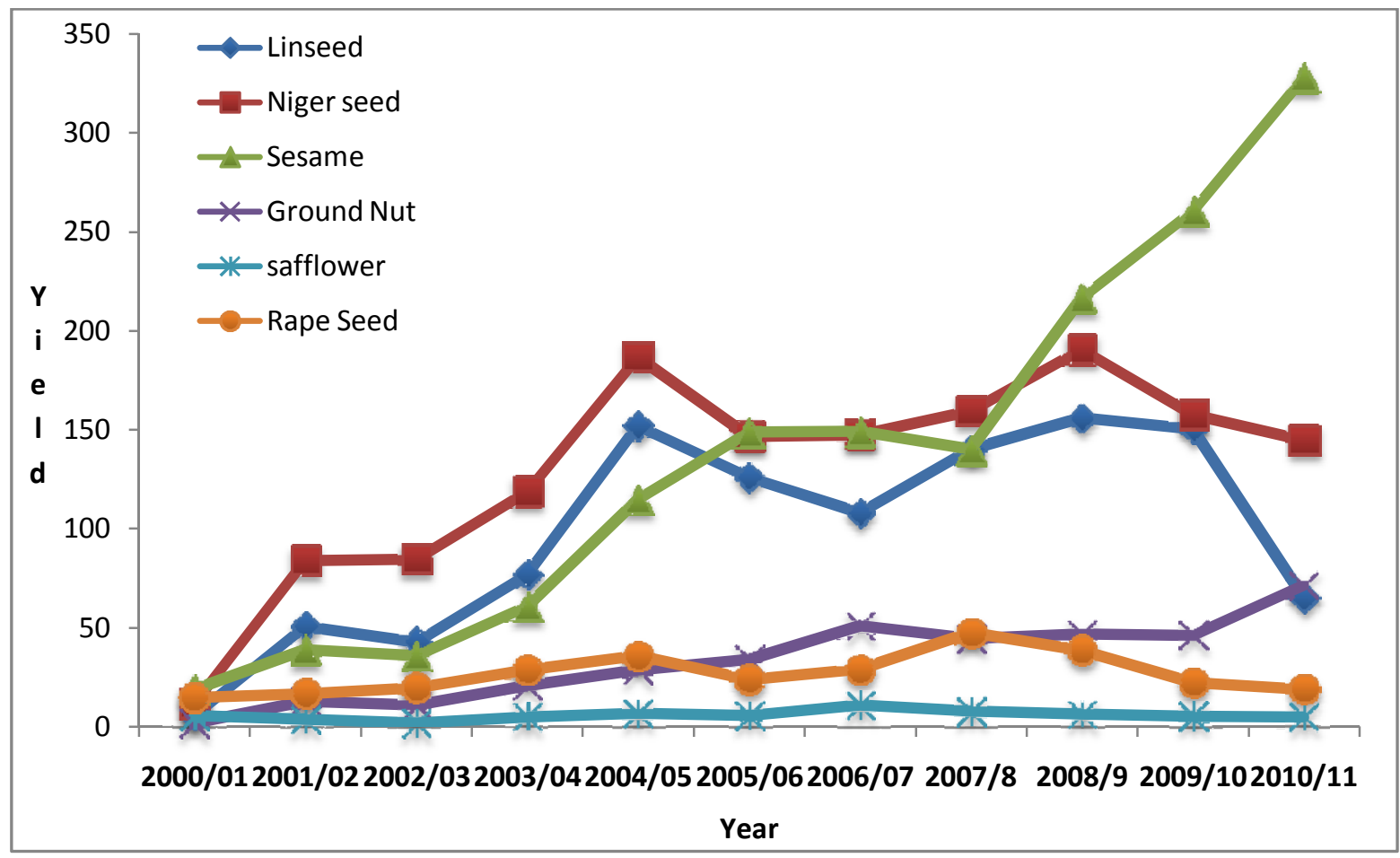

Figure 1: Total Yield Production of Major Oilseeds (1000 tons) in Ethiopia from 2000/01-2010/2011.

Table 2: Main export types of Ethiopian sesame varieties and their characteristics.

\begin{tabular}{|c|c|c|c|c|}
\hline No. & Varieties & $\begin{array}{l}\text { Market } \\
\text { Name }\end{array}$ & Characteristics & Applications \\
\hline 1 & $t-85$ & Humera & $\begin{array}{l}\text { Whitish larger seed, } \\
\text { Sweet taste, sweet aroma; } 48-50 \% \text { oil content } \\
\text { High productivity } \\
\text { High possibility of shattering losses }\end{array}$ & Bakery \\
\hline 2 & kelafo-74 & Gondar & White, good uniformity of seed & Bakery \\
\hline 3 & Mehado- 80 & Wollega & $\begin{array}{l}\text { Small seed; High oil content } 49-56 \% \text { and less } \\
\text { sweetness }\end{array}$ & Oil \\
\hline
\end{tabular}


Zerihun

\section{Ethiopian Commercial Sesame Seeds}

The Ethiopian quality sesame varieties are usually known by their brand name. There are three sesame variety types commonly used for commercial production and these are Humera, Gondar and Wollega types (Table 2). The commercial varieties are suitable for various applications. For instance, the Humera type is appreciated worldwide for its aroma and sweet taste. It is said to be good uniform white seeds, which are quite larger. This makes it very suitable for bakery products. The Gondar type is also suitable for the bakery market. The major competitive advantage of the Wollega type is its high oil content. The major quality requirements for sesame seed export are thousand seed weight should be greater than $3 \mathrm{~g}, 40-50 \%$ oil content, pearly-white seed color and $99 \%$ seed purity is required for export standard. Regarding quality of sesame seeds, white seeds with a white to golden color, are mainly used in raw form because of their aesthetic value and are mostly priced higher than mixed seeds (yellow to dark brown seeds) which are generally crushed into oil (Wijnands et al., 2007). Hulled seeds and bleached hulled seeds have a higher market value than untreated seeds. Different reports shows that there is an increasing demand internationally for Ethiopian sesame seed however, the Humera and Gondar types have higher in price than Wollega types (Wijnands et al., 2007; Dawit and Meijerink, 2010).

The traditional importers of Ethiopian sesame seed were China, Israel, Turkey and other Middle Eastern countries. While currently, the demand volume of the traditional buyers is continuing to increase and new importers such as Greece, Germany, The Netherlands and United Kingdom are also coming to the market (Sorsa, 2009).

\section{Major Challenges of Sesame Production in Ethiopia}

Despite its nutritional and high value crop, research on sesame has been limited worldwide and so that it has been produced under traditional management practices. Sesame yields are highly variable depending upon the growing environment, cultural practices and the type of cultivar. Sesame is a low yielder and worldwide average yields are low (Brigham, 1985). The major constraints in sesame production worldwide are lack of wider adapting cultivars, shattering of capsules at maturity, nonsynchronous maturity, poor stand establishment, lack of fertilizer responses, profuse branching, and low harvest index (Ashri, 1994). Besides this, lack of appropriate storage facilities and
Sci. Technol. Arts Res. J., July-Sep 2012, 1(3): 01-07

mechanical mixtures of different variety seeds has been reported as a problem in Ethiopia. Thus, blending of varieties should be avoided to provide adequate seed cleaning of up to 99$99.5 \%$ purity is required (Wijnands et al., 2007). Beside this, diseases and insect pests cause severe yield losses in Ethiopia. Thus, the most common pests registered include bacterial blight (Xanthomonas campestris pv. sesami), phyllody (Mycoplasma), Fusarium wilt (Fusarium oxysporum), powdery mildew (Oidium erysiphoides), Alternaria leaf spot (Alternaria sesame) and Cercospora leaf spot (Cercospora sesame). Bacterial blight is transmitted through Jassid (Orosius albicinctus). It is very common in humid and high rainfall areas, transmitted by infected seeds and while phyllody is a highly destructive disease. Sesame leaf roller or webworm (Antigasta catalaunalis) is also an important insect that damages sesame in Ethiopia (Tadele, 2005). In Uganda, sesame webworm (Antigastra catalaunalis) and sesame gall midge (Asphondylia sesami) were reported to be the major insect pest of sesame (Okidi, 2002; Ssekabembe et al., 2006). Ssekabembe (2007) indicated that two times application of pesticide for sesame pests after 2 and 4 weeks of crop emergence control the sesame webworm (Antigastra catalaunalis).while control of the gall midge (Asphondylia sesame) requires a systemic insecticide. On the other hand, half of the area under sesame crop in Gujarat state of India is suffering due to poor soil fertility and drought at vegetative stage (Dhandhalya and Shiyani, 2009). It can be suggested that efficient research strategy may be required to reduce the effect of various yield reducing factors in sesame production.

Despite the high potential for increased production of sesame and the rapidly growing demand in the international market for Ethiopian sesame, it has been observed that the supply chain of sesame also suffers from different challenges including the adulteration of sesame or mixing of sesame with different sources of varying quality and a lack of transparency among chain actors. Sesame being sold as plain seed, while quality characteristics such as oil content, percentage of admixture, fatty acid profile are not commonly analyzed due to lack of capacity to accurately measure the quality standards of sesame. Thus, it is believed that selecting and grading sesame according to its quality and clearly specifying its characteristics, such as its origin (for traceability), or whether it is organic or a speciality, etc., can create higher market prices as well as fulfill buyer expectations in the end market (Sorsa, 2009). This necessitates the 
Zerihun

coordination of different stakeholders at any stage in production, post harvest handling and processing steps to obtain better quality.

\section{Future Opportunities and Prospects of Sesame Production}

The current production of sesame seed is highly dependent on high marketable value and suitability of environmental conditions especially in the lowlands of North western and Southwestern areas. The suitability of environmental condition for sesame crop production and the presence of genetic diversity of sesame in Ethiopia would give better possibility or potential for improvement. The proximity of the country to international market and the high market demand for Ethiopian sesame seed can be considered as another opportunity. The oil qualities of varieties currently under production are relatively good and encouraging but needs to improve further. Though there is an effort by some research centres in Ethiopia in variety development and agronomic research but yet it is not enough to bring impact in increasing production and productivity of sesame. Diseases and insects are causing significant yield loss in sesame crop. The research attention that has been given to improve this crop is not comparable with the contribution of this crop in Ethiopian economy.

\section{REFERENCES}

Ashakumary, L., Rouyer, I., Takahashi, Y., Ide, Fukuda, T., Aoyama, N., Hashimoto., Mizugaki, T., Sugano, M. (1999). Sesamin, a sesame lignin is a potent inducer of hepatic fatty acid-oxidation in the rat metabolism. Clinical and experimental 48 (10):1303-1313.

Ashri, A. (1994). Genetic resources of sesame: Present and future perspectives. In: Arora, R.K. and Riley, K.W. (Eds). Sesame Biodiversity in AsiaConservation, Evaluation and Improvement, IPGRI Office for South Asia, New Delhi, India. Pp. 25-39.

Ashri, A. (1998). Sesame breeding. Plant Breeding Reviews, 16:179-228.

Ashri, A. (2007). Sesame (Sesamum indicum L.). In: Singh, R.J. (Eds.). Genetic resources, chromosome engineering and crop improvement.Vol. 4.: Oilseed crops. CRC press, Boca Raton. Pp.231-289.

Balasubramaniyan, P., Palaniappan, S.P. (2001). Field Crops: An overview. In: Principles and Practices of Agronomy, Agrobios, India. Pp. 47.

Bedigian, D. (2004). History and lore of Sesame in southwest Asia. Economic botany 58(3):329-353.

Bedigian, D., Harlan, J. (1986). Evidence for cultivation on sesame in the ancient world. Economic Botany 40:137-154.

Bedigian, D., Smyth, C., Harlan, J. (1986). Patterns of morphological variation in sesame. Economic Botany 40:353-365.

Bedigian, T. (1985). Sesamin, sesamolin and the original of sesame biochem systematics. Ecology 13:9-133.
Sci. Technol. Arts Res. J., July-Sep 2012, 1(3): 01-07

\section{CONCLUSION}

To solve the different challenges and improve production potential as well as quality of sesame crop, the use of improved technologies is highly recommended. Thus, it is important to focus on the following points:

- the need of the collaborative efforts of all concerned stakeholders including government organizations, researchers, NGOs, private investors and farmers...etc, in the improvement of the crop.

- Capacity building on sesame crop improvement and post harvest handling to maintain the quality of produce.

- Introduction and identification of better adaptable cultivars with better resistance to important diseases and pests.

- Development of high yielding potential variety with improved quality traits through application of modern breeding techniques.

- Development of improved agronomic and managemental practices.

- Environmental clustering for high oil quality as oil quality is influenced by environmental factors.

- Attention should be given to start refining processes for oil seeds in Ethiopia than importing refined edible oil with comparable value that is being obtained from expert earnings from oilseeds.

Brar, G., Ahuja, R. (1979). Sesame: its culture, genetics, breeding and biochemistry. Annual Review Plant Science 285-313.

Buss, J. (2007). Sesame production in Nampula: Baseline survey report, Clusa, Nampula, Mozambique .Pp.2-20.

Carlsson, A.S., Chanana, N.P., Gudu, S., Suh, M.C., Were, B.A. (2008). Sesame. In: Kole, C., (Eds.), Compendium of transgenic crop plant - Transgenic oilseed crops. Texas, USA: Wiley Blackwell, 2. Pp. 227-246.

CSA (Central Statistical Agency) (2007). Federal Democratic Republic Ethiopia: Central statistics Agency, Agricultural sample survey 2007/2008 (2000 E.C) (September-December 2007). Volume I: Report on: Area and production of crops (private peasant holdings, meher season), Statistical Bulletin 417, Addis Ababa, June, 2008. Pp.1-17.

CSA (Central Statistical Authority) (2009). Federal Democratic Republic Ethiopia: Central statistics Agency. Agricultural Sample survey 2008/9 (2001 E.C) (Sep-Dec 2008). Vol I. Report on Area and Production of crops (private peasant holdings, Meher season).Statistical Bulletin No: 446. Addis Ababa. Pp. 12-17.

CSA (Central Statistical Authority) (2011). Federal Democratic Republic Ethiopia: Central statistics Agency. Agricultural Sample survey 2010/11 (2003 E.C) (Sep-Dec 2010). Vol I. Report on Area and Production of major crops (private peasant holdings, Meher season). Statistical Bulletin. Addis Ababa. Pp. 12-96. 


\section{Zerihun}

Daniel, E.G., Parzies, H. K. (2010). Genetic variability among landraces of sesame in Ethiopia. African Crop Science Journal 19(1):1-13.

Dawit, A., Meijerink, G. (2010). The Ethiopian Commodity Exchange (ECX): An overview. A report prepared by Ethiopian Pulses, Oil seeds and spices processors Exporters Association, Public Private partnership and Wageningen University. Pp. 5-34 (www.dgis.wur.nl/NR/rdonlyres/.../Report4Alemu2806 10.pdf, date accessed 12/07/2012)

Dhandhalya, M.G., Shiyani, R.L.(2009). Production potentials, yield gaps and research prioritization of production constraints in major oilseed crops of Saurashtra region. Indian Journal of Agricultural Research 43(1):18-25.

FAOSTAT (2008). Food and agriculture organization of the United Nations. (Available online: http://faostat.fao.org/site/567/default.aspx\#ancor. (Accessed 20/07/2012).

Frank, T.O. (1998). Vegetable oils. Bailey's Industrial Oil and Fat Product 1:19-44.

Hatam, M., Abbasi, G.O. (1994). "Oilseed Crops" In: Crop production. BMC Genetics 358-362.

Hawkes, J. (1983). The diversity of crop plants Cambridge, Harvard University Press, 1983.

IBC (Institute of Biodiversity Conservation) (1996). Ethiopia: Country report to the FAO international technical conference on plant genetic resources (Leipzig, 1996). Plant Genetic Resources Center Addis Abeba, April 1995. Pp.17.

IBC (Institute of Biodiversity Conservation) (2007).Ethiopia: Second country report on state of plant genetic resource to FAO. Institute of Biodiversity conservation (IBC), Addis Ababa. Pp.16.

Kobayashi, T. (1981). The wild and cultivated species in the genus Sesamum. In: Sesame: Status and improvement, Proceed. Expert Consultation Rome, Italy, 8-12 December, 1980.FAO, Rome, Italy.157-162.

Langham, D.R., Riney, J., Smith, G., Wiemers, T., Peeper, D., Speed T. (2010). Sesame Producer Guide. (www.sesaco.com Date accessed 10/01/2012).

Laurentin, H.E., Karlovsky, P. (2006). Genetic relationship and diversity in a sesame (Sesamum indicum $L$.) germplasm collection using amplified fragment length polymorphism (AFLP). BMC Genetics 7:10.

O' Brien, R.D. (1998). Fats and oils, formulating and processing for applications. Technical Publishing, Company Inc. Lancaster, USA.

Okidi, J.R. (2002). Status and relative incidence \& damage from pests of Simsim in eastern \& northern Uganda. M.Sc. Thesis, Makerere University.

Ram, R., Catlin, D., Romero, J., Cowley, C. (1990). Sesame: New approaches for crop improvement. In Janick, J., Simon, J.E. (Eds.). Advances in new crops, Proceeding, Timber press, Portland. Pp. 225-228.

Salunkhe, D.K., Desai, B.B. (1986). Post harvest biotechnology of oilseeds.CRC press, Boca Raton, Florida. Pp.105-117.

Sharma, S.B. (1994). Utilization of national collections of sesame in India. In: Arora, R.K., Riley, K.W.(Eds), Sesame Biodiversity in Asia- Conservation, Evaluation and Improvement, IPGRI Office for South Asia, New Delhi, India. Status and Improvement, Proc. Expert Consultation, Rome, Italy, 8-12 December, 1980, FAO, Rome, Italy. pp. 157-163.
Sci. Technol. Arts Res. J., July-Sep 2012, 1(3): 01-07

Sorsa Debela. (2009). Sesame trade arrangements, costs and risks in Ethiopia: A baseline survey. Netherlands Ministry of Foreign Affairs Government, Wageningen University. Pp.12-64.

Speer, M. (2009). Baseline survey of sesame trade arrangements, costs and risks in Ethiopia draft report for Sesame Value Chain for Pro-Poor Development Projects. The Royal Netherlands Embassy, Addis Ababa, and LEI-Wageningen University and Research Centres, The Hague.

Ssekabembe, C.K., Okidi, J., Ogenga-Latigo, M., Nabasirye, M. (2006). Occurrence and species range of insect pests of Sismim in northern and eastern Uganda. Makerere University, Research Journal 1:2535.

Ssekabembe, C.K.(2007). Comparison of research on sesame (Sesamum indicum) and nakati (Solanum aethiopicum) at Makerere University. African Crop Science Society Vol. 8. pp. 2063-2069.

Tadele, A. (2005). Sesame (Sesamum indicum L.) Research in Ethiopia: a Review of Past Work and Potential and Future Prospects. Sesame and Safflower Newsletter 20, Food and Agriculture Organization, United Nation.

Tashiro, T., Fukuda, Y., Osawa, T.(1991). Oil contents of seeds and minor components in the oil of sesame, Sesamum indicum L., as affected by capsule position. Japan Journal of crop science. 60(1):116-121.

USAID (2008). USAID Ethiopia: Agribusiness and trade expansion program. (www.ethiopiaag.org /www.fintrac.com (date accessed 18/01/2010).

Uzun, B., Ulger, S., Cagirgan, M.I. (2002). Comparison of determinate and indeterminate types of sesame for oil content and fatty acid composition. Turkish Journal of Agriculture and Forestry 26(5): 269-274.

Wijnands, J., Biersteker, J., Hiel, R. (2007). Oilseeds Business Opportunities in Ethiopia. Survey report, Ministry of Agriculture, Nature and Food Quality, The Netherlands, The Hague. Pp.8-20

Wijnands, J., Biersteker, J., van Loo, E.N. (2009). Oilseeds Business opportunities in Ethiopia. Public Private Partnership, November 2009, The Hague, Netherlands. Pp.1-60.

Zenebe, M., Hussien, M. (2009). Study on Genotype X Environment Interaction of Oil Content in Sesame (Sesamum indicum L.). Middle-East Journal of Scientific Research, 4 (2): 100-104.

Zeven, A., Zhukovsky, P. (1975). Dictionary of cultivated plants and their centres of diversity Wageningen, PUDOC.http://www.fao.org/docrep/0 09//9325e/i9325e00.HTM\#21 